\title{
Elevated Mercury in Ambient Air and Soils Impacts of Historical Air Emissions (1897-1991) from a Chlor-Alkali Plant (CAP)
}

\author{
Gary Hunt \\ TRC Environmental Corporation, Lowell, USA \\ Email: ghunt@trcsolutions.com
}

Received 18 January 2016; accepted 26 February 2016; published 29 February 2016

Copyright (C) 2016 by author and Scientific Research Publishing Inc. This work is licensed under the Creative Commons Attribution International License (CC BY). http://creativecommons.org/licenses/by/4.0/

(c) (i) Open Access

\section{Abstract}

Mercury contamination was found to be widespread in soils at a property in Upstate New York. Historical site use suggested that the mercury did not result from prior industrial use of the property. Soil contamination may have resulted from atmospheric deposition of mercury released from properties in close proximity to the contaminated property. The purpose of this forensics investigation was to examine to what extent atmospheric deposition of elemental mercury may have influenced mercury levels found in surficial soils on the contaminated property and further to identify the source(s) of the mercury. Work efforts included an examination of historical records available for a chlor-alkali plant (CAP) upwind of the contaminated property to establish historical use and disposal practices for elemental mercury. Mercury emissions test data from the Upstate New York chlor-alkali facility were modeled (USEPA ISC3) as a means of estimating impacts on ambient air and soils vicinal to the facility. Mercury emissions from the facility were modeled as both a point source and volume source. For example, at a location 305 meters to the east and 30 meters to the north of the modeled source centerline elemental mercury concentrations in ambient air were estimated at $270 \mathrm{ng} / \mathrm{m}^{3}$ (average results based upon 5 years of meteorological data). This value is contrasted to a background concentration of $1.6 \mathrm{ng} / \mathrm{m}^{3}$ (USEPA Report to Congress 1997). As a result of the modeling data in combination with findings related to mercury use and disposal practices at the NY CAP documented from the records review, it was concluded that emissions from the CAP facility during the period of operation (1897-1991) most likely accounted for the concentrations of elemental mercury found in surficial soils at properties situated downwind of the CAP. These findings were further corroborated by information available in the open literature for CAPs world-wide.

\section{Keywords}

Mercury, Air Emissions, Chlor-Alkali (CAP) Manufacturing, Dispersion Modeling, Deposition Rates 


\section{Introduction}

\subsection{Chlor-Alkali Industry Overview}

The chlor-alkali industry represents the largest historical consumer of elemental mercury in the United States. (chlor-alkali production takes place using an electrochemical process in which elemental mercury is used as a liquid cathode in the electrolytic production of chlorine gas and alkali $(\mathrm{NaOH})$ from brine salts. Refer to Figure 1 for a schematic of a typical electro chemical cell used in a chlor-alkali production process). USEPA estimates that fourteen (14) facilities were in operation in the country in 1996 accounting for an estimated 7.13 tons of elemental mercury emissions to the atmosphere [1]. Mercury air emissions from these facilities were introduced to the environment by a combination of dry and wet deposition processes as well as gaseous dispersion.

\subsection{Study Purpose and Objectives}

Mercury contamination in soils at an industrial site in Niagara Falls, New York was widespread [2]. A review of historical site records indicated that mercury contamination was not the result of on-site uses. The presence of mercury in soils on a site wide basis, as well as, the patterns of mercury concentrations suggested atmospheric deposition from off-site sources. An examination of off-site sources (and in particular those situated upwind) was warranted to identify potentially responsible parties such that remediation costs incurred by the property owner could be recovered. These costs were incurred in the removal and disposal of mercury contaminated soils needed to restore the site to compliance with New York State Guidelines [2]. The primary objective of this study was to identify the most likely source(s) of elevated mercury concentrations found in soils at the industrial site in Niagara Falls, New York.

\subsection{Description of Site and Environs}

The property is located at 3163 Buffalo Avenue in Niagara Falls, New York within a highly industrialized region of the city in close proximity to the Niagara River. The property is comprised of 5.7 acres and historically housed a variety of chemical operations dating from the 1940's. Based upon review of available records none of these prior operations used or handled mercury [2]. A property situated directly west of 3163 Buffalo Avenue (and situated upwind) was identified and selected for further study. The property had housed a variety of chemical operations dating from the 1800's. These operations included electrolytic production of chlorine and caustic soda from rock salt using mercury cell chloralkali production processes (see Figure 1). The CAP commenced production in 1897 and remained in operation until 1991. Figure 2 provides an aerial photograph of the study region noting the location of the NYCAP, the 3163 Buffalo Avenue property, and the CAP cell room used in the dispersion modeling analyses. (Each cell room at a CAP houses numerous mercury electrolytic cells used in the chloralkali production process).

\subsection{Study Approach}

The study approach consisted of the following key elements:

1) An examination of all available records for the NYCAP related to mercury handling and disposal practices during the period 1897-1991 was conducted.

2) Identification of historical sources of mercury emissions (point and fugitive).

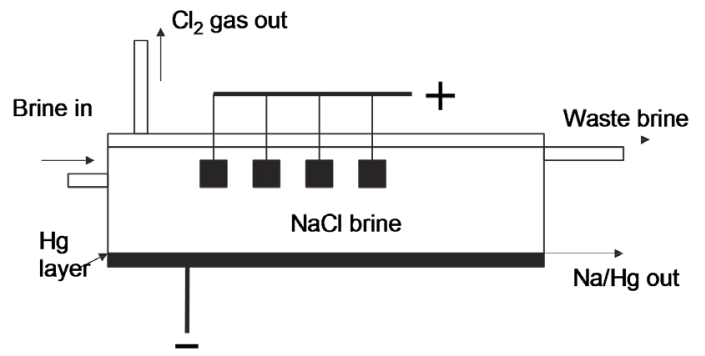

Figure 1. Chloralkali production process-typical cell reproduced with permission from Hites (2007). 


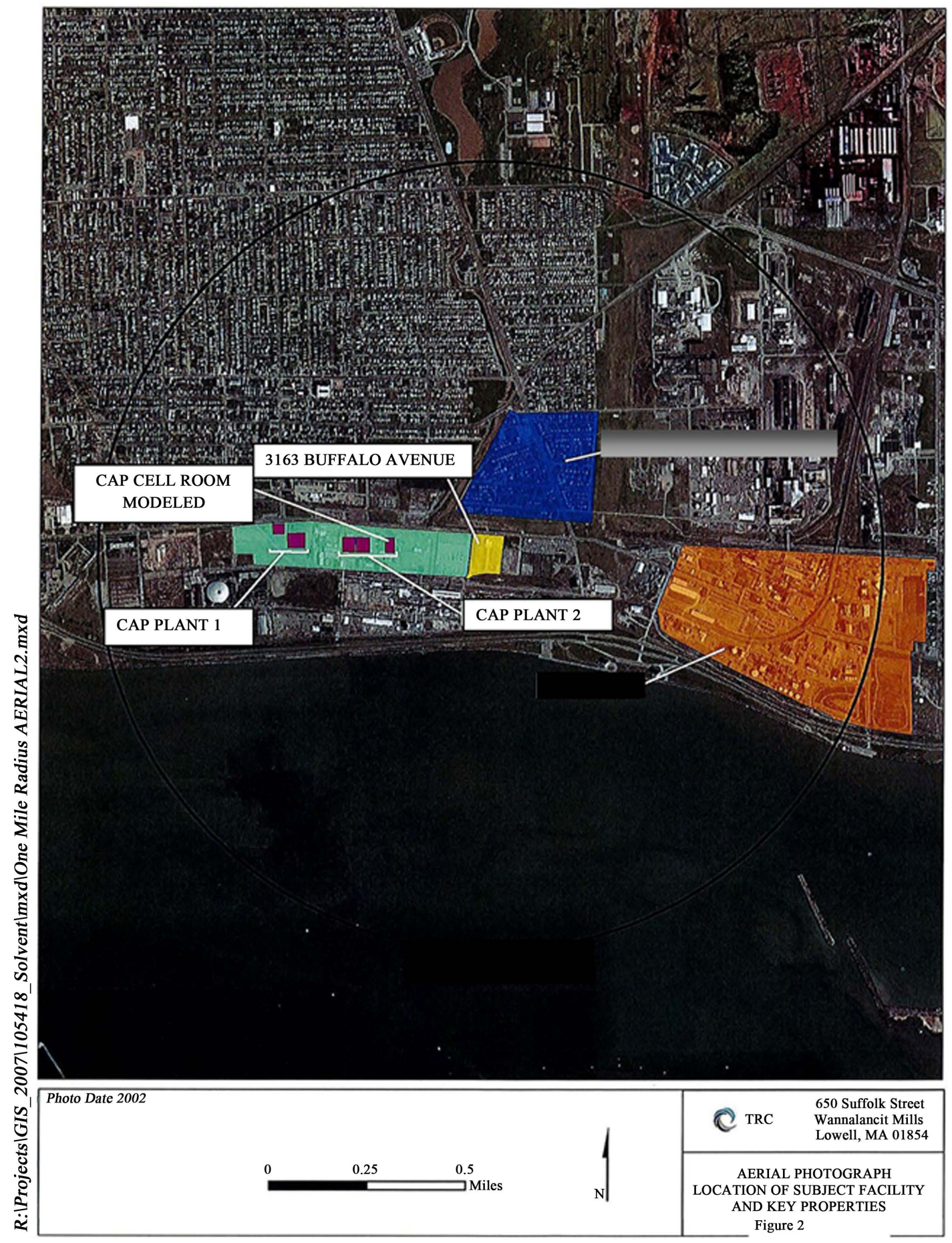

Figure 2. Aerial photograph of subject facility and key properties.

3) Development of emissions rates for identified sources using actual air emissions data (if available) for a representative period of operation for the NYCAP.

4) Performance of atmospheric dispersion modeling of emissions to estimate ambient air concentrations of mercury in the vicinity of the NYCAP.

5) Comparison of estimated ambient air concentrations to ambient background for mercury, as well as, mercury concentrations (both measured and estimated) in the vicinity of other CAPs worldwide. 
6) Comparison of mercury concentrations present in soils at the 3163 Buffalo Avenue property to the following data sets:

a) Mercury in soils upwind of the NYCAP.

b) Background concentrations measured in soils characteristic of other US locations.

c) Mercury concentrations measured in soils in the vicinity of other CAPs worldwide.

7) Researching of the environmental impacts attributable to other CAPs worldwide. Summarize ambient air and soil mercury concentrations in the vicinity of these facilities and determine the relevance of these data to defining the environmental impacts of the NYCAP.

In summary, to what extent could the results from each of these elements collectively be used to attribute mercury concentrations found in soils at 3163 Buffalo Avenue to mercury emissions from the NYCAP.

\subsection{Environmental Impacts of Chlor-Alkali Industry-Historical Review and Global Case Studies}

The primary objective of this study was to identify the most likely source(s) of elevated mercury concentrations found in soils on an industrial site in Niagara Falls, New York. A three phase approach was employed as stated previously. One phase included an examination of mercury use at CAPs worldwide and their associated environmental impacts by means of a review of the open literature. The results of this review are summarized here.

\subsection{The Chlor-Alkali Industry in the United States}

The chlor-alkali industry represents the largest historical consumer of elemental mercury in the United States. USEPA estimates that 28 facilities were in operation in 1973 [3]. This number decreased to 14 facilities based upon a 1991 census [1]. A listing of these chlor-alkali plants remaining in 1996 adapted from the EPA Mercury Study Report to Congress-Volume II [1] is provided in Table 1. Nine of these facilities were still in operation in 2005. Since then the majority have either been closed or have phased out the use of mercury in the manufacture of chlorine and caustic soda. The latter has most commonly included conversion to mercury free cell membrane technology.

\subsection{Mercury in Soils Vicinal to CAPs—Global Case Studies}

Environmental contamination attributable to mercury emissions from five Swedish chlor-alkali plants was investigated in 1971 [4]. The highest concentrations were found in snow samples collected in the first kilometer downwind from the plants. Levels decreased markedly thereafter. The localized mercury contamination was

Table 1. 1996 U.S. mercury-cell chlor-alkali production facilities [1].

\begin{tabular}{|c|c|c|c|c|}
\hline Facility & Location & Capacity $10^{3} \mathrm{Mg} / \mathrm{yr}$ & Capacity $10^{3}$ tons/yr & 1994 emissions Mg/yr \\
\hline $\begin{array}{l}\text { Georgia-Pacific Corp., } \\
\text { Chemical Division }\end{array}$ & Bellingham, WA & 82 & 90 & 0.585 \\
\hline BF Goodrich, Chemical Group & Calvert City, KY & 109 & 120 & 0.382 \\
\hline Hanlin Group, Inc., & Reigelwood, NC & 48 & 53 & 0.497 \\
\hline LCP Chemicals Division & Orrington ME & 76 & 80 & 0.264 \\
\hline ASHTA Chemicals, Inc. & Ashtabula, $\mathrm{OH}$ & 36 & 40 & 0.753 \\
\hline \multirow{3}{*}{$\begin{array}{l}\text { Occidental Petroleum Corp., } \\
\text { Electrochemicals }\end{array}$} & Deer Park, TX & 347 & 383 & 0.472 \\
\hline & Delaware City, DE & 126 & 139 & 0.231 \\
\hline & Muscle Shoals, AL & 132 & 146 & 0.106 \\
\hline \multirow{2}{*}{$\begin{array}{l}\text { Olin Corporation, } \\
\text { Olin Chemicals }\end{array}$} & Augusta, GA & 102 & 112 & 0,597 \\
\hline & Charleston, TN & 230 & 254 & 0.684 \\
\hline $\begin{array}{l}\text { Pioneer Chlor-Alkali } \\
\text { Company Inc. }\end{array}$ & St. Gabriel, LA & 160 & 176 & $\mathrm{~N} / \mathrm{A}$ \\
\hline PPG Industries, Inc., & Lake Charles, LA & 233 & 256 & 0.558 \\
\hline Chemicals Group & New Martinsville, WV & 70 & 77 & 0.513 \\
\hline $\begin{array}{l}\text { Vulcan Materials Company, } \\
\text { Vulcan Chemicals Division }\end{array}$ & Port Edwards, WI & 65 & 72 & $\mathrm{~N} / \mathrm{A}$ \\
\hline
\end{tabular}


linked to CAP source emissions and in particular the hydrogen stack. Mercury deposition in the vicinity of a Finnish chlor-alkali plant was examined. Dry and wet deposition rates were measured employing the moss-bag sampling technique [5]. The average net deposition rate (wet + dry) of $480 \mu \mathrm{g} / \mathrm{m}^{2}$ annually was a factor of 60 times above background deposition rates $\left(8 \mu \mathrm{g} / \mathrm{m}^{2}\right.$ per year). In an earlier study the same authors measured a net deposition rate of $1200 \mu \mathrm{g} / \mathrm{m}^{2} /$ year for mercury again in close proximity to a Finnish chlor-alkali plant [6]. This deposition rate represented a factor of 150 times above the background value measured during the same study. Biester, Muller and Scholer examined mercury levels in the vicinity of three (3) chlor-alkali plants (CAPs) in Europe [7]. Surface soils collected at all three sites contained highly elevated mercury concentrations in comparison to local background levels. Soil enrichment factors for mercury were 56 fold for Site S1. Soil concentrations ranged from $24.2 \mu \mathrm{g} / \mathrm{kg}$ to $4188 \mu \mathrm{g} / \mathrm{kg}$ with a mean concentration of $442 \mu \mathrm{g} / \mathrm{kg}$. The highest mercury concentrations were found in surface soils along the prevailing downwind vector at a distance approximately 0.25 $\mathrm{km}$ from the plant. The authors concluded that mercury enrichment in the forest soils was attributable to atmospheric deposition and filtering followed by foliage uptake. Mercury concentrations in soils vicinal to CAP Site 2 ranged from 122 - $3005 \mu \mathrm{g} / \mathrm{kg}$. Mean and median concentrations were $674 \mu \mathrm{g} / \mathrm{kg}$ and $541 \mu \mathrm{g} / \mathrm{kg}$, respectively. The higher mean and median concentrations at this site indicated more widespread contamination attributable to mercury emissions from this CAP. Local background soil concentrations applicable to this location were estimated to be $150 \mu \mathrm{g} / \mathrm{kg}$. The highest mercury concentrations were found in surface soils along the prevailing downwind vector within $0.5 \mathrm{~km}$ south of the CAP. The authors concluded that dry deposition was the predominant process for mercury deposition in the vicinity of chlor-alkali plants. (See Figure 3 for the distribution of mercury in surface soils within a 1-km distance of European CAP S2). Gonzalez (1991) reported on mercury contamination in soils and a biomonitor (mimosa pudica or "garden poppy") in the vicinity of a chlor-alkali plant in Cuba [8]. The highest concentrations were reported in samples collected within a $0.5 \mathrm{~km}$ distance from the CAP along the prevailing downwind direction. Beyond a $5 \mathrm{~km}$ distance it was not possible to discern differences in concentrations from what was observed at remote or background sites. A vertical soil profile was obtained at a sampling location approximately $0.3 \mathrm{~km}$ downwind of the chlor-alkali mercury emissions source. These data clearly demonstrated that mercury concentrations were enhanced in the soil surface layers and directly attributable to atmospheric deposition.

\subsection{Ambient Air Levels Vicinal to CAPs—Global Case Studies}

The EPA Mercury Study Report to Congress states that atmospheric concentrations of elemental mercury in the vicinity of chlor-alkali facilities are significantly higher than background concentrations [1] [9]. This is particularly true at locations along downwind vectors from the process emissions. An Italian CAP study [10] reported

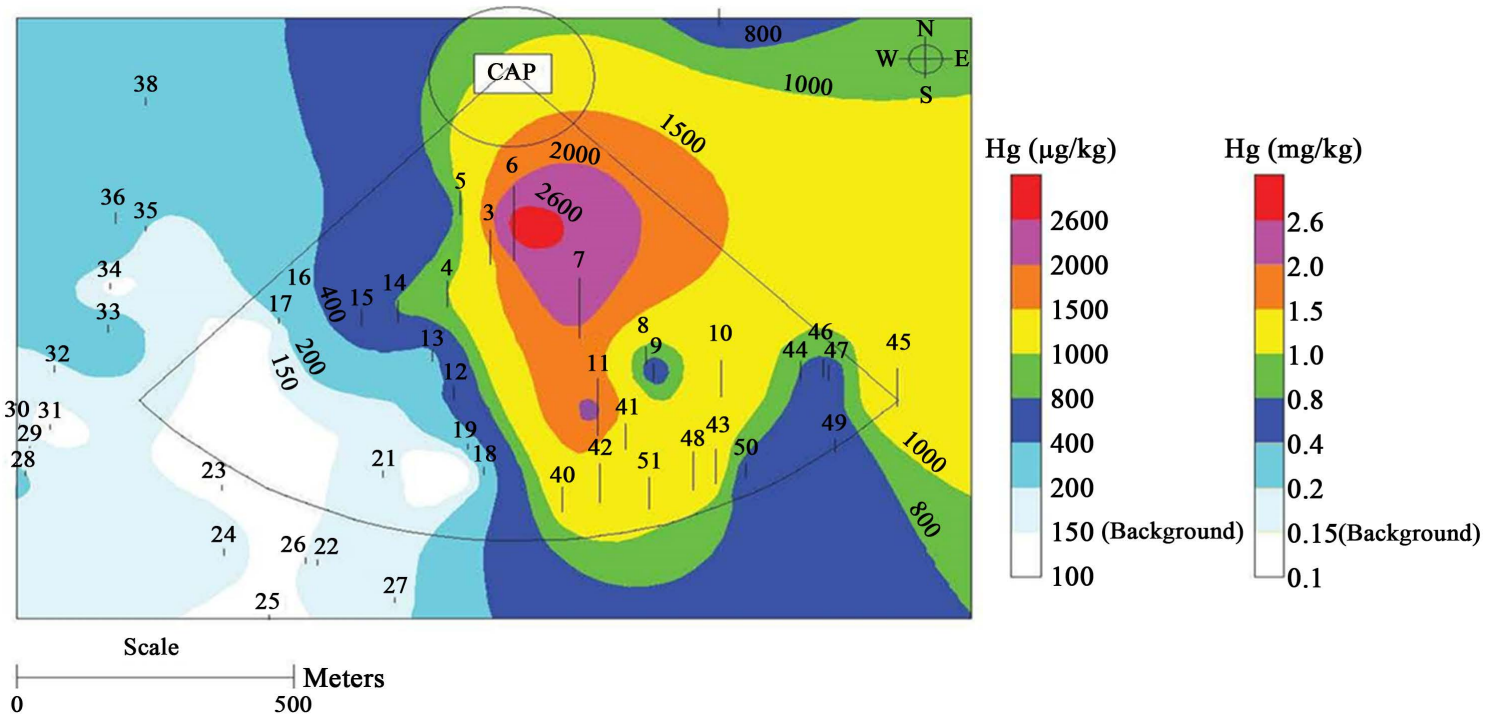

Figure 3. Distribution of Mercury in Surface Soils within 1-km Distance from European CAP S2 (Along Main Wind Directions). Reproduced with permission from Biester et al. 2002. 
the highest mercury concentrations in ambient air at sampling locations near the electrolytic cell rooms. Concentrations reported at these locations and along downwind vectors were 3 - 4 times higher than background levels measured at coastal sites in central Italy. Swedish researchers, reporting on mercury levels in the vicinity of two chlor-alkali plants in that country [11] observed that the majority of the mercury released into the atmosphere was elemental mercury emitted from the ventilation system atop the roof of the cell room. Mean concentrations of $43.82 \mathrm{ng} / \mathrm{m}^{3}$ of elemental mercury were reported at a sampling site situated $0.25 \mathrm{~km}$ downwind of the plant (see Table 2 for a summary of ambient mercury levels in the vicinity of four (4) European CAPs). This study identified non-point source emissions from surficial soils as a major contributing factor to atmospheric mercury concentrations in the vicinity of the chlor-alkali plant. This study suggests that wet and dry deposition of mercury vapors from the chlor-alkali plant has caused significant contamination in surface soils downwind of the plant and that, moreover, these contaminated soils represent a significant source of fugitive emissions of mercury that persists beyond the operational life cycle of the chlor-alkali plant.

\section{Methodology-Air Dispersion Modeling}

\subsection{Mercury Emissions CAP Upstate NY}

An emissions estimate of $787 \mathrm{~g}$ /day was selected to represent actual mercury emissions from the NYCAP. This estimate based upon actual emissions data [13] [14] provided by the CAP was used in the atmospheric dispersion modeling analyses to assess the environmental impacts associated with the CAP during the facility's period of operation. The $787 \mathrm{~g}$ /day value represents a highly conservative estimate for actual mercury likely to have been emitted from the CAP during its long operating history. This value represented an emission rate of 1.73 lbs/day or $633 \mathrm{lbs}$ over the course of a year. This annual emission rate conservatively represents 57,000 lbs or 28.5 tons of elemental mercury released to the atmosphere during an estimated 90 years of operation at the Niagara Falls site. The $787 \mathrm{~g}$ /day emissions rate represents a small fraction of the quantity of mercury consumed or lost on a daily basis. Air emissions represent an estimated 4\% of mercury consumed or lost at the Niagara Falls CAP based upon daily plant records for the period 1952-53 (see Figure 4). This rate is based only on actual process streams sampled in each of the compliance tests and in effect discounts mercury emissions from other process streams present and not sampled. Further, this emissions estimate does not include any contributions from secondary emissions sources comprised primarily of fugitive emissions of mercury already in place at the Niagara Falls property. These include artifacts from prior mercury spills, as well as fugitive emissions from contaminated surface soils at the CAP property. Much higher mercury emissions were likely associated with the CAP during its many years of operation. The NYCAP's own data developed for meeting EPA TRI (Toxic Release Inventory) reporting requirements for the calendar years 1988-1990 indicated that mercury emissions averaged $1751 \mathrm{~g} /$ day for this period of operation (see Figure 5). These estimates are further substantiated by the value of 1742 g/day representing plant-wide emissions calculated using an alternate approach based upon actual CAP test data (see Figure 5). TRI emission rates for CAPs located in Georgia [15], Tennessee and other locations across the United States [1] are also shown for comparison purposes.

Table 2. Atmospheric Hg concentrations vicinal to CAP.

\begin{tabular}{|c|c|c|}
\hline Location/site & Concentrations (ng/m³) & Reference \\
\hline \multicolumn{3}{|l|}{ Bohus/Sweden: } \\
\hline $0.25 \mathrm{Km}$ from chlor-alkali plant & 43.82 & {$[11]$} \\
\hline $0.50 \mathrm{Km}$ from chlor-alkali plant & 26.55 & {$[11]$} \\
\hline $1.5 \mathrm{Km}$ from chlor-alkali plant & 20.93 & {$[11]$} \\
\hline $5.0 \mathrm{Km}$ from chlor-alkali plant & 19.46 & {$[11]$} \\
\hline Huelva (Spain) & $96.00($ mean $)(\mathrm{N}=5538)$ & [12] \\
\hline Torrela Vega (Spain) & $41.00(\mathrm{~N}=4401)$ & {$[12]$} \\
\hline Monzon (Spain) & $362.3(\mathrm{~N}=3901)$ & [12] \\
\hline
\end{tabular}




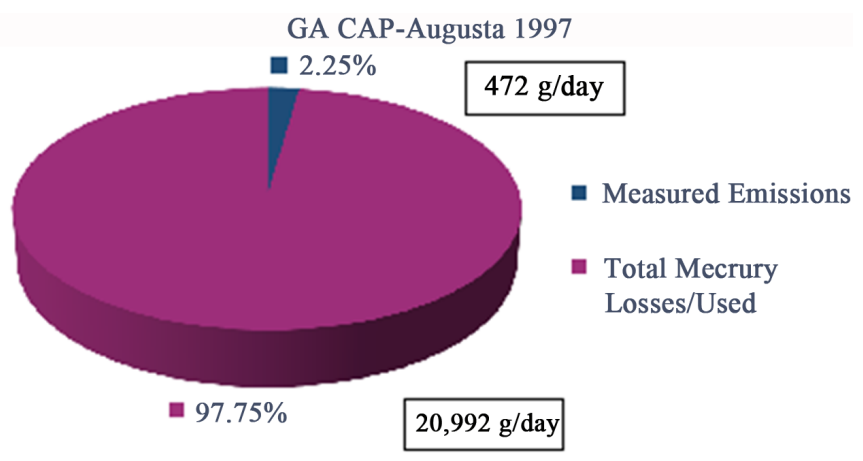

NY CAP-Niagara Falls 1952-1953

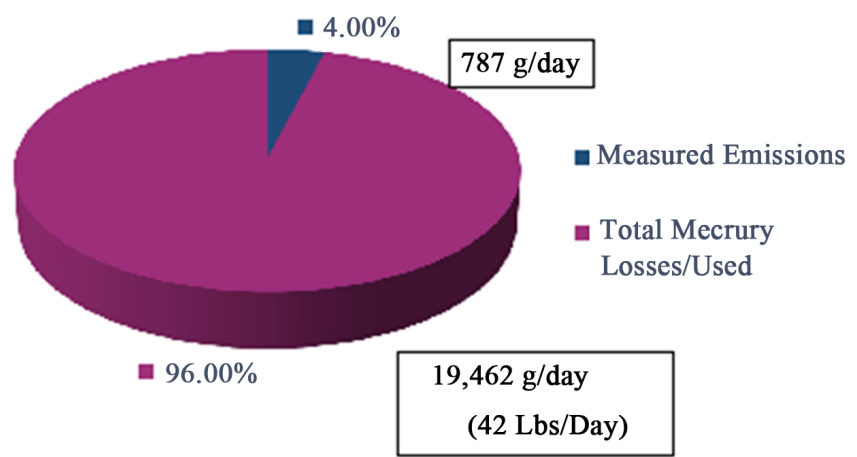

Augusta GA data derived from 197 EPA Study [15].

Niagara Falls, NY data derived from Daily Plant Logs (1952-1953) [2].

Figure 4. Air emission as a function of total hg consumption at CAPs.

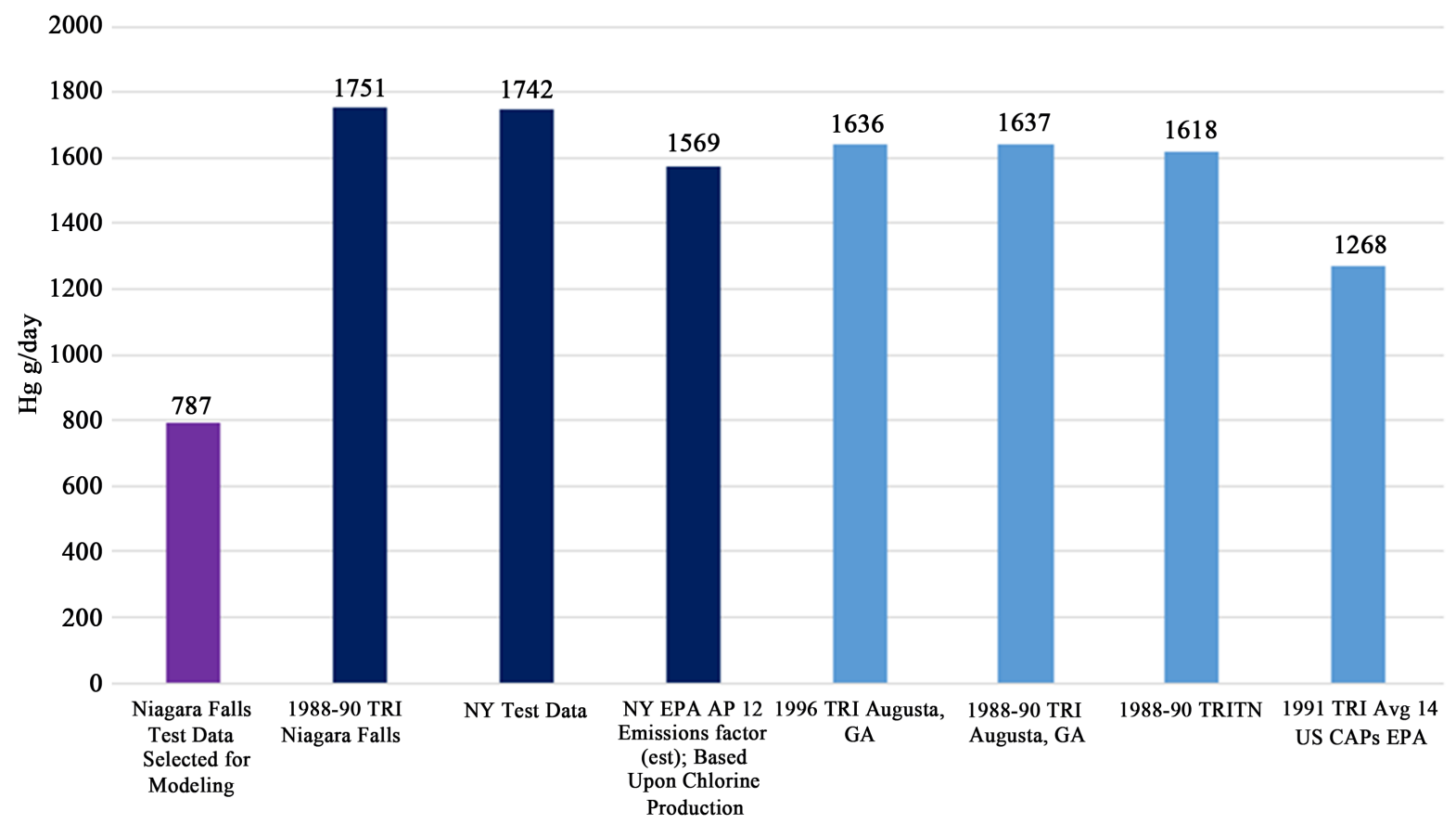

Figure 5. Comparison of Hg daily emissions rates (g/day) - Niagara falls, GA, TN and other U.S. CAPs. 
The selected emission rate of $787 \mathrm{~g} /$ day is the lowest of all the rates estimated (see Figure 5) and is approximately one-half of many of the other estimated values shown (including those reported by the NYCAP). This approach was taken to ensure that the predicted mercury impacts would not be over represented, especially given the scatter in the testing data [13] [14]. However, it is important to remember that the resulting ambient air concentrations and deposition rates presented in Section 3 underestimate those that actually occurred due to the use of the conservative emission rate. Use of any of these higher emission rates (see Figure 5) in the dispersion modeling analyses would result in corresponding increases in predicted concentrations of mercury in ambient air and deposition rates to surface soils. The increases would be arithmetic or simply a ratio of the higher emission rate divided by $787 \mathrm{~g} /$ day. For example, $1751 \mathrm{~g} /$ day/787g/day would result in a factor of 2.2. This factor when applied would effectively double all of the estimates or predicted concentrations and deposition rates reported in Section 3 to follow.

\subsection{Meteorological Data}

Concurrent five-year records (1985-1989) of hourly meteorological data were obtained from Buffalo Airport and Niagara Falls Airport and then processed into composite wind roses. The wind rose for Niagara Falls showed a greater westerly component than did the wind rose for the same time period at Buffalo. Given the much closer proximity of the Niagara Falls Airport to the site and the differing orientations of major bodies of water near the two airports, the meteorological data from Niagara Falls were selected as most representative for the site and were used in subsequent modeling analyses to estimate the transport and dispersion of mercury emissions from the NYCAP. The wind rose for Niagara Falls Airport showed winds from the west-southwest were most frequent (approximately $11 \%$ on average). West winds were nearly as frequent (about $10 \%$ ), while south, southsoutheast, and southeast winds each occurred about $8 \%$ of the time on average. Concurrent upper air data from Buffalo Airport were used to determine mixing heights and were incorporated in the modeling analyses. Buffalo Airport was the closest site for which upper air data needed to estimate mixing height were available.

\subsection{Dispersion Modeling}

The EPA Industrial Source Complex Model (ISC3) was selected for use in this modeling study. ISC3 is recommended for use in EPA's “Guideline on Air Quality Models” (EPA, 2003 [16]) for a wide range of regulatory applications. ISC3 is a steady-state Gaussian plume model and is well suited for predicting impacts from complicated industrial sources. It can model a wide range of source configurations (point, area, and volume sources and flares) and incorporates algorithms that account for plume rise and dispersion, the effects of terrain, building downwash, and the deposition of particles. Thus, ISC3 was particularly well suited for use in this modeling study based on its ability to model various source types and to account for building downwash effects associated with short stacks located on or near buildings. ISC3 was used by EPA in its Report to Congress as the model of choice for assessing near-field (within $50 \mathrm{~km}$ ) impacts from mercury emitting sources [1] [9]. The ISC3 model is described fully in the "User's Guide for the Industrial Source Complex (ISC3) Dispersion Models" (USEPA, 1995 [17]). ISC3 was used in its short-term configuration for the modeling analysis. In its short-term mode, ISC3 uses a series of hourly meteorological records to predict hourly average concentrations that are then averaged to obtain concentrations for averaging periods longer than one-hour. The model was run using regulatory default values recommended by EPA. The model was run using rural dispersion coefficients. This selection was made based on the results of a land use classification analysis conducted in accordance with procedures recommend in the EPA “Guideline on Air Quality Models.” In this procedure, the percentages of various industrial, commercial, residential, and agricultural/natural land use categories within a 3-km radius centered on the site were determined. Rural or urban dispersion coefficients were then specified based on the category that predominated. The analysis for the area centered on the downwind site and yielded a preponderance of rural land use categories. Standard air dispersion modeling techniques were used to estimate the transport and diffusion of mercury emissions from the NYCAP to downwind properties. Since it was not possible to reconstruct the exact layout and source configuration of the Niagara Falls CAP it was not possible to determine exactly how mercury was emitted to the atmosphere from the facility when it was in operation (e.g., the number and location of vents/stacks and the corresponding exhaust gas characteristics). As a result, two emission release scenarios were developed to represent and bracket the range of possibilities. In one case, a volume source representation was used. In the other, a point source was modeled. Results are presented for both modeled source representations 
(i.e., volume source and point source). The modeling analyses treated mercury emissions from the NYCAP as a gas, since the emissions would be expected to be in the form of vapor. This is consistent with the approach used by EPA for modeling studies of chlor-alkali plants contained in the Report to Congress [1] [9].

1) Volume Source Approach

In the volume source approach, it was assumed that all the mercury emissions were released from a series of passive vents located on the walls and roof of the cell building (see Figure 2 for location of cell room used as source of mercury emissions). Mechanical turbulence generated by the interaction of the wind field with the structure would have the effect of enhancing the initial mixing of the emissions. In this approach, the emissions from the cell building were represented as an elevated volume source. An elevated volume source is commonly used to represent emissions from elevated, non-buoyant sources, such as roof monitors or building vents, whose emissions occupy an initial volume. The volume source algorithm in ISC3 is based on a virtual point source approach, in which an imaginary (or virtual) point source is modeled at a distance upwind in order to account for the initial size of the volume source. For this analysis, given the uncertainty regarding the details of the source geometry, the mercury emissions were represented by a single volume source. Horizontal dimensions of the cell building were estimated based on information obtained from a review of site maps and photographs of the CAP in Niagara Falls [2]. Estimates of building height (51 feet), building length (200 feet), and building width (125 feet) were based on information for a similar chlor-alkali plant operated in Augusta, Georgia [15] owned by the same company that owned and operated the NYCAP. Since ISC3 requires that volume sources have a square footprint, the cell building was represented by a square structure with an equivalent area (see Figure 2). This yielded a representative building horizontal dimension of approximately 158 feet. Dimensions of the representative volume source were then defined in accordance with guidance in the ISC3 User's Guide [17]. The guidance for elevated volume sources located on or adjacent to a building is to use a height equal to the building, an initial lateral dimension given by the building length (represented here by the typical horizontal dimension of 158 feet) divided by 4.3, and an initial vertical dimension given by the building height divided by 2.15.

2) Point Source Approach

In the point source approach, it was assumed that all mercury vapor was emitted to the atmosphere via a single stack located adjacent to the cell building. The stack height was assumed to equal the building height, and horizontal dimensions for the cell building were used with the EPA Building Profile Input Program Preprocessor (BPIP) to determine the projected building parameters needed by ISC3 to incorporate the effects of building downwash. The point source was modeled using a stack exit diameter of 6 inches, a negligible exit velocity (0.1 meters per second), and a near ambient stack temperature to minimize any plume rise.

3) Receptor Data

The modeling analysis was conducted using a Cartesian (rectangular) receptor grid centered on the NYCAP. Receptors are locations at which the model predicts concentrations. The grid measured $4 \mathrm{~km}$ by $4 \mathrm{~km}$ and used a fine receptor spacing of 50 meters. Additional receptors were placed along the northwest corner of the downwind property (approximately 305 meters to the east) and along the edge of a nearby residential area (approximately 300 meters to the east-northeast). Flat terrain was assumed in the modeling, since there were no significant terrain variations in the inner part of the grid that covered the area of primary interest for the study.

\subsection{Atmospheric Deposition Modeling and Rates of Deposition on Soils}

Volume III of the Report to Congress [9] addresses the speciation of mercury by source type. All mercury emissions from chlor-alkali plants were assumed to be in vapor form with 70 percent being elemental mercury $\left(\mathrm{Hg}^{0}\right)$ and the balance, or 30 percent, being divalent mercury $\left(\mathrm{Hg}^{+2}\right)$. The same apportionment was assumed in the modeling for the NYCAP.

For deposition modeling of the NYCAP, a representative annual average dry deposition velocity for divalent mercury was calculated through a review and analysis of the values presented in Table 4-3 of Volume III of the Report to Congress [9] and the meteorological data from Niagara Falls. First, the 5-year meteorological data record from Niagara Falls (1985-1989) was processed to obtain the frequency of occurrence of each stability category in each season. Next, the "urban" land use category was selected as the category most representative for the area over which the modeling was conducted. The other land-use categories for which deposition velocities were presented were less representative of the study area in this analysis. Finally, an annual average value for a dry deposition velocity for divalent mercury was calculated by weighting the deposition velocities listed in 
Table 4-3 [9] for urban areas for various seasons and stability categories by the frequency of occurrence of these conditions in Niagara Falls. The resulting average dry deposition velocity for divalent mercury is $3.8 \mathrm{~cm} / \mathrm{s}$. This value is over 60 times higher than the corresponding dry deposition velocity for elemental mercury.

Total dry deposition of mercury was estimated as follows. The total predicted gaseous mercury concentrations at ground level $\left(\chi_{T}\right)$ were be apportioned into elemental $\left(\chi_{0}\right)$ and divalent $\left(\chi_{2}\right)$ components based on the 70/30 apportionment of the gaseous mercury emissions [9]:

$$
\chi_{T}=\chi_{0}+\chi_{2}=0.7 \chi_{T}+0.3 \chi_{T} .
$$

The dry deposition $(D)$ of each component was then calculated as the product of the predicted ambient air concentration at ground level $(\chi)$ and the applicable deposition velocity $(v)$ as shown here: (The subscripts 0 and 2 refer hereafter to the elemental and divalent forms of mercury).

$$
D_{T}=D_{0}+D_{2}=\chi_{0} v_{0}+\chi_{2} v_{2} .
$$

Substituting values of $0.06 \mathrm{~cm} / \mathrm{s}$ for $v_{0}$ and $3.87 \mathrm{~cm} / \mathrm{s}$ for $v_{2}$ yields:

$$
D_{T}=1.203 \chi_{T} \text {. }
$$

If the total predicted concentration is presented in units of $\mathrm{ng} / \mathrm{m}^{3}$, then the total dry deposition of gaseous mercury in units of milligrams per square meter per year $\left(\mathrm{mg} \cdot \mathrm{m}^{-2} \cdot \mathrm{yr}^{-1}\right)$ can be represented by:

$$
D_{T}=0.379 \chi_{T} \text {. }
$$

The Report to Congress [9] observed that although wet deposition can dominate the total deposition for receptors close to a source, dry deposition accounted for most of the total deposition for chlor-alkali plants. For this reason, only dry deposition of mercury was estimated for the area surrounding the NYCAP in Niagara Falls including the property located at 3163 Buffalo Avenue. The results presented in Section 3do not include any consideration of wet deposition of gaseous mercury.

\section{Results and Discussion}

\subsection{Mercury in the Environment-Background in Ambient Air and Soils}

A literature survey was performed to establish mercury concentrations in ambient air representative of background and not influenced by contributions from CAPS or other mercury emitting sources. These data were used for comparison to concentrations in ambient air predicted by dispersion modeling (see Sections 3.6 and 3.7 Results and Discussion) and directly attributable to air emissions from the NYCAP.

\subsection{Background Ambient Air Levels}

The Expert Panel on Mercury Atmospheric Processes cited in the EPA Report [9] considered the background concentration in the atmosphere over the northern hemisphere as ranging from $1.5-2.0 \mathrm{ng} / \mathrm{m}^{3}$. The same report considered $1.6 \mathrm{ng} / \mathrm{m}^{3}$ to represent a reasonable estimate of atmospheric background in the Continental United States. The majority of the mean concentrations reported for continental US sites in Table 3 are in good agreement with the $1.5-2.0 \mathrm{ng} / \mathrm{m}^{3}$ value. Mean and upper limit concentrations reported in Table 3 suggest that a background concentration approaching $5.0 \mathrm{ng} / \mathrm{m}^{3}$ to be a more conservative estimate of mercury in the atmosphere.

\subsection{Mercury in Soils-Background Concentrations}

Background concentrations for mercury in surface soils were needed for comparison to levels present in soils at the 3163 Buffalo Avenue site directly downwind of the NYCAP. Some background and reference concentrations used in the comparison are summarized in Table 4. These include concentrations in soils upwind of the NYCAP, values reported for soils in New York State, other US locations, as well as, surface soils upwind of several European CAPs.

Additionally, a comprehensive data-base of mercury levels in surficial soils of the continental United States was generated by the US Geological Survey [28]. Concentrations ranged from $0.033 \mathrm{ppm}(\mathrm{mg} / \mathrm{kg})$ in remote areas to $0.382 \mathrm{ppm}(\mathrm{mg} / \mathrm{kg})$ in some of the more industrialized regions of the country. Mercury in soils from sites in East St Louis, an industrialized urban setting, ranged from ND-1.7 mg/kg [29]. The mean concentration 
Table 3. Measured vapor phase atmospheric mercury concentrations.

\begin{tabular}{|c|c|c|}
\hline Location/area type & $\mathrm{ng} / \mathrm{m}^{3}$ mean (range) & Reference \\
\hline Chicago, IL & $8.7(1.8-62.7)$ & [18] \\
\hline Lake Michigan & $2.3(1.3-4.9)$ & [17] [18] \\
\hline South Haven, MI & $2.0(1.8-4.3)$ & [18] [19] \\
\hline Ann Arbor, MI & 2.0 (max. 4.4) & [18] [19] \\
\hline Detroit, MI Site B & $3.7(\max 8.5)$ & [18] \\
\hline Underhill Center, VT & $2.0(1.2-4.2)$ & [20] \\
\hline Broward County, FLBackground Site nearAtlantic Ocean (Site 1) & 1.8 & [21] \\
\hline Broward County, FLInland (Site 2) & 3.3 & [21] \\
\hline Broward County, FLInland (Site 3) & 2.8 & [21] \\
\hline Little Rock Lake, WI & $1.6(1.0-2.5)$ & [22] \\
\hline Crab Lake, WI & 1.7 & [23] \\
\hline French Guiana, Dorlin Camp Hill/Rural & $5.4 \pm 1.6$ & {$[24]$} \\
\hline French Guiana, Petie Saut Lake/Rural & $2.8 \pm 1.4$ & [24] \\
\hline French Guiana, Background Levels/Pristine & $(1.0-4.0)$ & [24] \\
\hline Bondville, IL/(background) & $2.0 \pm 0.5(1.3-3.8)$ & [25] \\
\hline Chicago, IL/Urban & $3.6 \pm 2.9(1.6-22.1)$ & [25] \\
\hline Kenosha, WI/Rural & $2.2 \pm 0.7(1.1-5.7)$ & [25] \\
\hline Sleeping Bears Dunes, MI/Rural & $2.1 \pm 0.7(1.4-5.0)$ & [25] \\
\hline South Haven, MI/Rural & $2.2 \pm 0.7(1.4-6.1)$ & [25] \\
\hline France, Champ Sur Drac/Suburban & $3.4 \pm 3.6(1.9-4.8)$ & [26] \\
\hline Antarctica, Neumayer Station/Pristine & $1.08 \pm 0.29(0.27-2.34)$ & [27] \\
\hline
\end{tabular}

Table 4. Hg in soils—-some background/reference concentrations—-mg/kg.

\begin{tabular}{cccc}
\hline Soil type/location & Description/source & $\mathrm{mg} / \mathrm{kg}$ & Reference \\
\hline NY CAP Site & Upwind CAP (South and West) Composite Samples & 0.003 & {$[2][30][31]$} \\
Niagara Falls & Surface Soils_-Niagara Falls Board of & & {$[2]$} \\
NY State & Health_Clean-up Target-Site Remediation & 0.50 & {$[9]$} \\
US & Surface Soils (Control) & 0.12 & {$[9]$} \\
East St, Louis, MO & Typical Soils_NJDEP 1993; US EPA Report & $0.008-0.117$ & {$[29]$} \\
Europe & Surface Soils (63 Sample Set) & 0.150 & {$[7]$} \\
Europe & Surface Soils-Upwind CAP & 0.075 & {$[7]$} \\
\hline
\end{tabular}

of $0.17 \mathrm{mg} / \mathrm{kg}$ for the 63 sample set is well below the maximum surface soil concentration of $0.382 \mathrm{mg} / \mathrm{kg}$ found in the USGS survey.

\subsection{Mercury Handling and Disposal Practices at the NYCAP}

Large quantities of elemental mercury were used on a routine basis during the long operating history (1897-1991) 
of the NYCAP. Mercury containing process wastes were routinely disposed of on the CAP property and at a landfill off site [2]. In calendar year 1977 alone 23,355 pounds (11.7 tons) of mercury containing process wastes were disposed of in this manner [2]. It is likely that larger quantities of elemental mercury were used, lost or disposed of prior to the advent of record keeping required for regulatory compliance. For example, National Emissions Standards for Hazardous Air Pollutants (NESHAPs) in 1973 [3]. The highly conservative 787 g/day emission rate selected for the dispersion modeling analyses potentially represents 59,475 lbs. or 29.7 tons of elemental mercury released to the atmosphere by the NYCAP during an estimated 94 years of operation. Air emissions represent an estimated $4 \%$ of mercury consumed at the NYCAP based upon daily plant records for the 1952-53 calendar period (see Figure 4 and Reference 2). Air emissions exceeding regulatory limits of 2300 g/day imposed by NESHAPs [3] were also documented [2].

\subsection{Mercury in Soils at the 3163 Buffalo Avenue Property}

A series of soil composite samples were collected at the 3163 Buffalo Avenue property during remedial investigations performed at the site [32] [33]. A total of 21 soil samples were collected and analyzed. Mercury concentrations ranged from 0.26 to a maximum of $443 \mathrm{mg} / \mathrm{kg}$. Mean concentrations for the 21 sample set were as follows: mean (without max) 6.50 and mean (with max) 29.3. These mean values even without consideration of the $443 \mathrm{mg} / \mathrm{kg}$ value as an outlier are significantly higher than any of the background soil concentrations shown in Table 4.

\subsection{Dispersion Modeling of NYCAP Emissions-Impacts on Ambient Air at 3163 Buffalo Avenue}

\section{1) Volume Source Scenario}

Figure 6 shows isopleths of the predicted ambient concentrations superimposed on a USGS map of the local area. The modeling results are based on the use of a volume source release configuration. The figure displays results for the five modeled years 1985-1989 expressed as an average. The figure displays the same general features, namely maximum impacts predicted near the NYCAP and sharp concentration gradients with distance. Maximum concentrations tend to be predicted to the east and north-northwest of the New York CAP. The maximum overall impact from the CAP is predicted to occur to the east of the source at the nearest modeled receptor (50 meters). It is not unusual to have maximum concentrations predicted immediately downwind of a nonbuoyant volume source. The combined effect of a relatively small emission height, initial mixing, and lack of buoyancy would typically yield maximum impacts nearby. The results can also be used to characterize ambient mercury impacts over parcels downwind of the CAP. The northwest corner of the property line of the 3163 Buffalo Avenue property is located about 305 meters to the east and 30 meters to the north of the center of the modeled CAP. The property extends further to the east about 120 meters and to the south about 170 meters. The maximum concentrations over the site were predicted to occur in the northwest corner of the site. The predicted impacts at this location vary from year to year with a maximum value of $300 \mathrm{ng} / \mathrm{m}^{3}$ and an average value of about $270 \mathrm{ng} / \mathrm{m}^{3}$. Concentrations decrease with distance to the southeast corner of the site where annual average concentrations of approximately $110 \mathrm{ng} / \mathrm{m}^{3}$ are predicted. An average value for the entire site would be approximately $190 \mathrm{ng} / \mathrm{m}^{3}$.

\section{2) Point Source Scenario}

The maximum overall impact from the NYCAP is predicted to occur to the east of the source at the nearest modeled receptor (50 meters). It is again common to have maximum concentrations predicted immediately downwind of a point source subject to significant building downwash effects (i.e., sources with very short stacks on or adjacent to buildings). The pattern and nature of impacts obtained from the point source release configuration are similar in many respects to those obtained from the volume source release configuration. The magnitude of the overall maximum impact is approximately $10 \%$ lower using the point source configuration than was observed using the volume source configuration. The results can also be used to characterize ambient mercury impacts over parcels downwind of the CAP. The maximum concentrations over the 3163 Buffalo Avenue property again predicted to occur in the northwest corner of the site. The predicted impacts at this location vary from year to year with a maximum value of $273 \mathrm{ng} / \mathrm{m}^{3}$ and an average value of approximately $240 \mathrm{ng} / \mathrm{m}^{3}$. Concentrations decrease with distance to the southeast corner of the site where annual average concentrations of approximately $100 \mathrm{ng} / \mathrm{m}^{3}$ are predicted. An average value for the entire site would be approximately $175 \mathrm{ng} / \mathrm{m}^{3}$. The impacts 


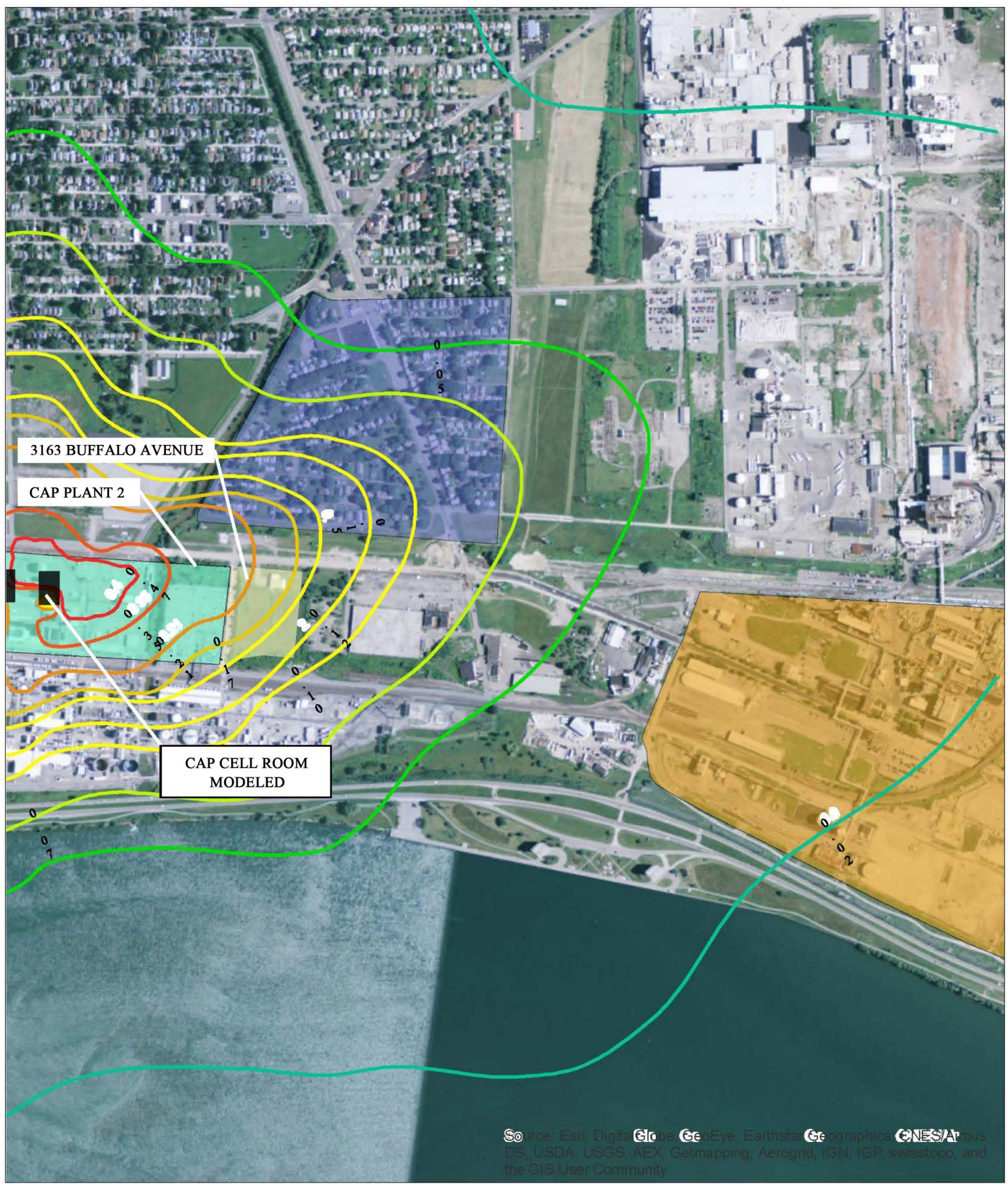

\section{CONCENTRATION (UG/M3)}

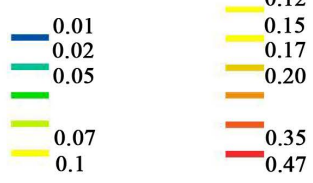

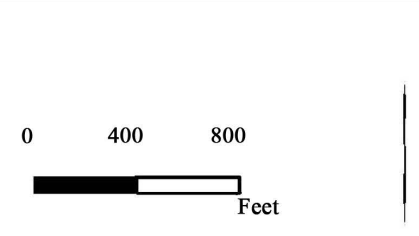
$\begin{array}{ll} & 650 \text { Suffolk Street } \\ \text { TRC } & \text { Wannalancit Mills } \\ \text { Lowell, MA 01854 }\end{array}$

Predictive Annual Average

Mercury Concentrations for NYCAP

Volume Source Configuration (1985-1989) Figure 6

Figure 6. Predictive annual average mercury concentrations in ambient air. 
predicted over the site using the point source release configuration are again slightly lower (10\%) than those obtained using the volume source release configuration. The mercury impacts predicted from the NYCAP at a distance of $2.5 \mathrm{~km}$ are roughly comparable to but somewhat larger than those predicted by EPA [9]. Average annual predicted impacts at $2.5 \mathrm{~km}$ from the NYCAP were approximately $8 \mathrm{ng} / \mathrm{m}^{3}$. These levels are similar to the results from EPA's modeling of model plants in the sense that they are distinguishable from predicted or estimated background levels (1.7 ng/ $\mathrm{m}^{3}$ in the EPA study in the Report to Congress). Of more interest are the impacts predicted at shorter downwind distances from the NYCAP and how they relate to monitoring results that appear in the literature. For example, monitoring studies conducted near a chlor-alkali facility found that measured mercury levels in the air decrease rapidly within a few hundred meters from a chlor-alkali facility [10] [34] [35]. The modeling results for the NYCAP (see Figure 6) show a similar rapid decrease in concentration with distance over several hundred meters no matter what source release configuration is assumed. The predicted mercury concentrations over the 3163 Buffalo Avenue site are approximately two orders of magnitude (100 times) greater than vapor-phase mercury concentrations measured in ambient air at various locations throughout the world including background levels observed in the United States (see Table 3). For example, at a location 305 meters to the east and 30 meters to the north of the modeled source centerline elemental mercury concentrations in ambient air were estimated at $270 \mathrm{ng} / \mathrm{m}^{3}$ (average results based upon 5 years of meteorological data). Table 5 provides a summary of the maximum and average mercury in air concentrations estimated using both the volume and point source dispersion modeling scenarios. These values are contrasted to a background concentration of $1.6 \mathrm{ng} / \mathrm{m}^{3}$ [9].

The maximum and mean ambient concentrations (Table 5) estimated for the 3163 Buffalo Avenue property also exceed concentrations measured in the vicinity of a number of European CAPs as shown in Table 2.

\subsection{Atmospheric Deposition of Mercury}

\section{1) Dry Deposition-Volume Source Release Configuration}

Figure 7 presents the pattern of calculated dry deposition of mercury attributable to emissions from the NYCAP. These results are based on the use of a volume source release configuration and the composite 5-year average predicted ambient concentrations. The deposition rates shown represent annual averages for the 5-year period examined. The predicted pattern of dry deposition provides some insight regarding those areas in the vicinity of the NYCAP that were most likely to have been effected by the dry deposition of mercury emissions from the facility.

Average dry deposition of mercury due to emissions from the NYCAP was estimated to range between about $102 \mathrm{mg} / \mathrm{m}^{2}$ per year at the northwest corner of the 3163 Buffalo Avenue property and $42 \mathrm{mg} / \mathrm{m}^{2}$ per year at the southeast corner of the property. An average dry deposition value over the property would be approximately 72 $\mathrm{mg} / \mathrm{m}^{2}$ per year.

2) Dry Deposition-Point Source Release Configuration

Average dry deposition of mercury due to emissions from the NYCAP was estimated to range between about $91 \mathrm{mg} / \mathrm{m}^{2}$ per year at the northwest corner of the 3163 Buffalo Avenue property and $38 \mathrm{mg} / \mathrm{m}^{2}$ per year at the southeast corner of the property. An average dry deposition value over the entire property would be approximately $66 \mathrm{mg} / \mathrm{m}^{2}$ per pear.

The total mercury deposition rates for the 3163 Buffalo Avenue Property estimated from dispersion modeling of the NYCAP emissions averaged $72 \mathrm{mg} / \mathrm{m}^{2}$ per year for the volume source scenario and $66 \mathrm{mg} / \mathrm{m}^{2}$ per year for

Table 5. Predicted air concentrations at 3163 Buffalo Avenue downwind of CAP in comparison to US background levels.

\begin{tabular}{cccc}
\hline Ambient air $\left(\mathrm{ng} / \mathrm{m}^{3}\right)$ & Source type & Value type & Maximum \\
270 & Volume & Maximum $\quad$ NW corner site & Mean corner site \\
240 & Point & Molume & Mean \\
190 & Point & Site wide & Mean wide \\
175 & - & US background
\end{tabular}




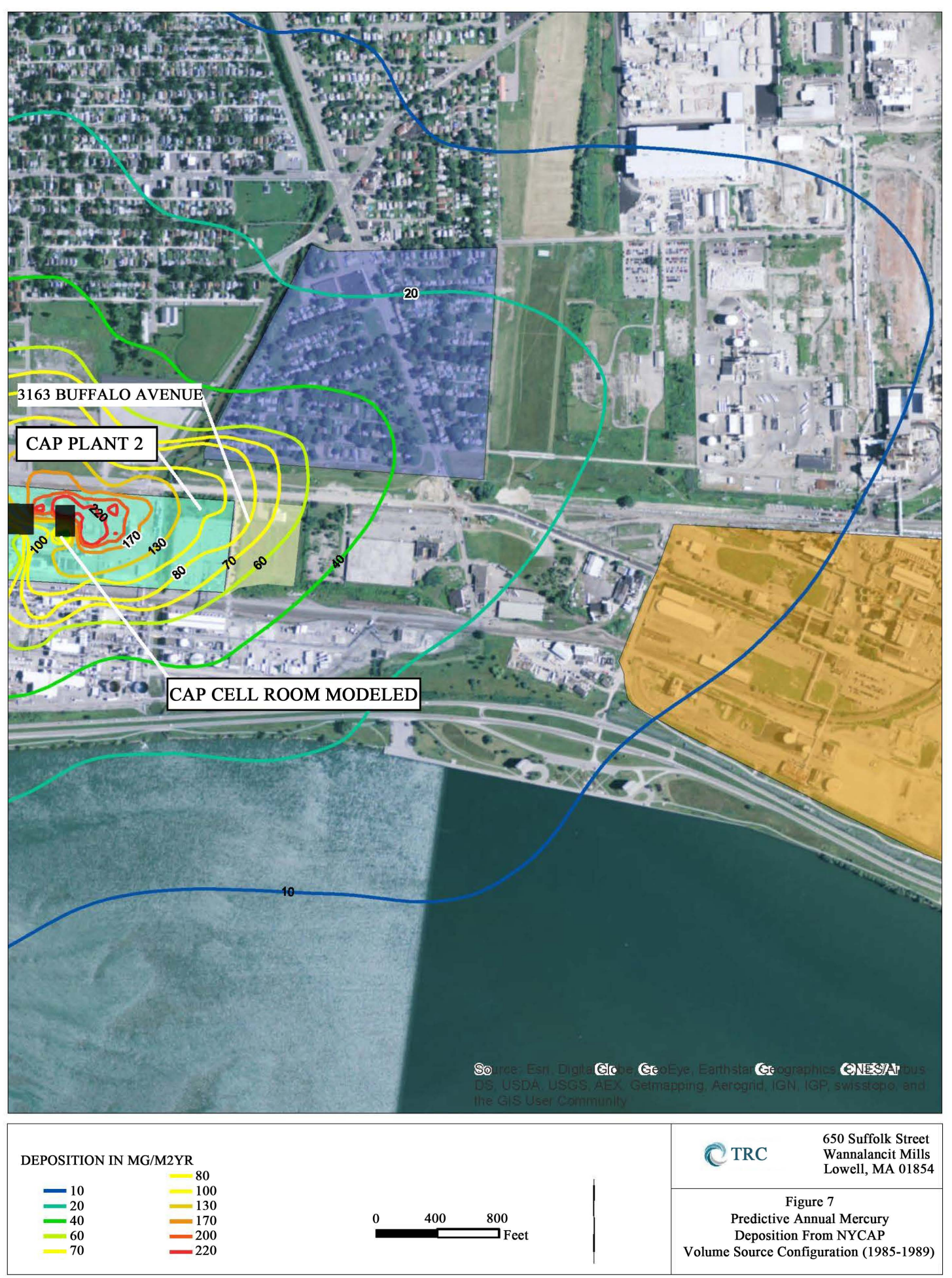

Figure 7. Predictive annual mercury deposition from NYCAP volume source configuration (1985-1989).

the point source scenario. Both of these values exceed the deposition rates reported as part of the European CAP study by factors ranging from 8 - 30 [7]. Deposition rates developed for the NYCAP would be expected to result in much higher mercury concentrations in surficial soils downwind of the site than was reported in the open literature for the European CAPs [7]. 
Deposition rates for mercury ranging from $7-25 \mu \mathrm{g} / \mathrm{m}^{2}$ per year have been reported to represent global background deposition rates for mercury in the atmosphere [5] [6]. The dry deposition rates for mercury in soils at the 3163 Buffalo Avenue site estimated from mercury emissions from the NYCAP on a annual basis are over three-four orders of magnitude (1000 - 10,000 times) higher than these background deposition rates.

A net mercury deposition rate of $2475 \mu \mathrm{g} / \mathrm{m}^{2}$ per year was reported for European CAP-1 [7]. This deposition rate in concert with 28 years of mercury emissions from the CAP resulted in soil concentrations with an upper limit of $4.18 \mathrm{mg} / \mathrm{kg}$ and a mean concentration of $0.44 \mathrm{mg} / \mathrm{kg}$. Assuming a period of operation (28 years) for the NYCAP (to allow for direct comparison to the European CAP) deposition rates of $66-72 \mathrm{mg} / \mathrm{m}^{2}$ per year could be expected to result in surficial soil concentrations with a mean of $11.8-12.9 \mathrm{mg} / \mathrm{kg}$ along the downwind direction $0.25 \mathrm{~km}$ from the NYCAP $\left(66 / \mathrm{m}^{2}\right.$ per year divided by $2.47 \mathrm{mg} / \mathrm{m}^{2}$ per year $=26.7 ; 26.7 \times 0.44 \mathrm{mg} / \mathrm{kg}=$ $11.8 \mathrm{mg} / \mathrm{kg}$ ). These values provide further justification for the widespread mercury contamination found in soils at the 3163 Buffalo Avenue property ranging from $0.26-23.4 \mathrm{mg} / \mathrm{kg}$.

\section{Summary}

\subsection{The Chlor-Alkali Industry and Environmental Impacts on a Global Basis}

The chlor-alkali industry represents the largest historical consumer of elemental mercury in the United States. Large quantities of mercury were typically consumed or used annually at each CAP, as well as over the CAPs period of operation. Air emissions to the atmosphere represent but a small percentage ( $2 \%-4 \%)$ of the total quantity consumed or used. The most significant pathway for introduction of mercury to the vicinal environment was emissions of elemental mercury to the atmosphere from chlor-alkali process emissions points. These include but are not limited to cell room roof top vents, hydrogen reactors stacks, end box vents and fugitive or secondary emissions from a variety of sources including contaminated soils. Mercury air emissions from these facilities were introduced to the environment by a combination of dry and wet deposition processes as well as gaseous dispersion. The environmental impacts are most pronounced in areas $0.25-1.0$ kilometers downwind of the facility. As a result, mercury levels in both ambient air and surficial soils in the immediate vicinity and especially locations downwind of chlor-alkali facilities are typically significantly above corresponding background levels. (>100 times background). The mercury contamination found in soils in the immediate vicinity of these CAPs is a systemic and widespread global problem. Soil contamination appears to be their legacy even after the CAPs are no longer operational and the attendant process emissions have ceased.

\subsection{NYCAP Emissions Impacts on Ambient Air Concentrations}

Predicted impacts on ambient concentrations of mercury as a result of air emissions from the NYCAP at locations downwind of the CAP were found to be significant. For example, at a location 305 meters to the east and 30 meters to the north of the modeled cell source centerline elemental mercury concentrations in ambient air were estimated at $270 \mathrm{ng} / \mathrm{m}^{3}$ annually (average results based upon 5 years of meteorological data). This value is contrasted to a background concentration of $1.6 \mathrm{ng} / \mathrm{m}^{3}$ (USEPA Report to Congress 1997). Predicted ambient concentrations were comparable (10\% difference) for both the volume and point source NYCAP emissions scenarios and comparable to or higher than concentrations estimated or measured downwind of other CAPs globally at comparable distances.

\subsection{Mercury in Soils at 3163 Buffalo Avenue and Likely Origins}

Mercury in shallow soils at the 3163 Buffalo Avenue site was widespread with the majority of the samples having mercury concentrations ranging from $0.26-23.4 \mathrm{mg} / \mathrm{kg}$. Such concentrations are well above what has been established as the upper limit for mercury burdens in US surface soils including urban industrialized regions of the country. The lower end of the range of concentrations are comparable to what is viewed as the upper limit for mercury contamination in the studies cited.

Predicted dry deposition rates of mercury on the 3163 Buffalo Avenue site attributable to the NYCAP emissions range between 38 and $102 \mathrm{mg} \cdot \mathrm{m}^{-2}$ per year with average values of approximately $70 \mathrm{mg} \cdot \mathrm{m}^{-2}$ per year. Predicted deposition rates (site wide average) for the volume $\left(72 \mathrm{mg} \cdot \mathrm{m}^{-2}\right.$ per year and point source scenarios (66 $\mathrm{mg} \cdot \mathrm{m}^{-2}$ per year) were found to be comparable (10\% difference). Mercury deposition rates of this magnitude over a period of years would be expected to yield significant quantities of mercury deposited to the surface soils 
on the property. For example a 28 year period of operation could be expected to results in surficial soil concentrations of 11.8 to $12.9 \mathrm{mg} / \mathrm{kg}$ at a location $0.25 \mathrm{~km}$ downwind of the NYCAP. Soil mercury concentrations at the site are consistent with concentrations found downwind of other CAPs worldwide and moreover CAPs with lower mercury deposition rates than were calculated for the Niagara Falls CAP.

\section{Conclusion}

The findings presented here collectively provide compelling evidence that mercury emissions from the Niagara Falls CAP over time were most likely responsible for the widespread mercury contamination found in soils on the 3163 Buffalo Avenue property.

\section{References}

[1] United States Environmental Protection Agency (US EPA) (1997) Mercury Study Report to Congress, Volume II: An Inventory of Anthropogenic Mercury Emissions in the United States, Office of Air Quality Planning \& Standards and Office of Research and Development, EPA-452/R-97-004.

[2] Hunt, G. (2004) Environmental Impacts of Historical Mercury Emissions-Chemical Facility in Niagara Falls, New York Final Expert Report Prepared by Gary Hunt (TRC) for Jaeckle Fleischman and Mugel, LLP Buffalo New York. (TRC Project 32734-0010)

[3] United States Environmental Protection Agency (US EPA) (1973) National Emission Standards for Hazardous Air Pollutants-Mercury Part 61.50 Federal Register, Vol. 38, No. 66.

[4] Arne, J. and Thomas, W. (1973) Air-Borne Mercury Fall-Out on Snow around Five Swedish Chlor-Alkali Plants. Atmospheric Environment, 7, 209-214. http://dx.doi.org/10.1016/0004-6981(73)90170-4

[5] Lodenius, M. (1998) Dry and Wet Deposition of Mercury Near a Chlor-Alkali Plant. The Science of the Total Environment, 213, 53-56. http://dx.doi.org/10.1016/S0048-9697(98)00073-4

[6] Lodenius, M. and Tulisalo, E. (1984) Environmental Mercury Contamination around a Finnish Chlor-Alkali Plant. Bulletin of Environmental Contamination and Toxicology, 32, 439-444. http://dx.doi.org/10.1007/BF01607520

[7] Biester, H., Müller, G. and Schöler, H.F. (2002) Estimating Distribution and Retention of Mercury in Three Different Soils Contaminated by Emissions from Chlor-Alkali Plants: Part I. The Science of the Total Environment, 284, 177189. http://dx.doi.org/10.1016/S0048-9697(01)00884-1

[8] Gonzalez, H. (1991) Mercury Pollution Caused by a Chlor-Alkali Plant. Water, Air, and Soil Pollution, 56, 83-93. http://dx.doi.org/10.1007/BF00342263

[9] United States Environmental Protection Agency (US EPA) (1997) Mercury Study Report to Congress. Vol. III, Fate and Transport of Mercury in the Environment, EPA-452/R-97-005.

[10] Maserti, B.E. and Ferrara, R. (1991) Mercury in Plants, Soil and Atmosphere near a Chlor-Alkali Complex. Water, Air, and Soil Pollution, 6, 15-20. http://dx.doi.org/10.1007/BF00342257

[11] Högström, U., Enger, L. and Svedung, I. (1979) A Study of Atmospheric Mercury Dispersion. Atmospheric Environment, 13, 465-476. http://dx.doi.org/10.1016/0004-6981(79)90140-9

[12] Lymberidi, E. (2006) Risky Business No Need for Mercury in the Chlorine Industry. Zero Mercury Working Group and European Environmental Bureau.

[13] Galson Technical Services, Inc. (1987) Source Emission Testing Dilute Caustic End Box Vent. Galson Project E7-001.

[14] Galson Technical Services, Inc. (1986) Source Test Report, Mercury Emission Testing of the Dilute Caustic End Box Vent (EP 18) at the Olin Corporation Chlor-Alkali Facility (Niagara Falls, NY). Galson Project \#G6-504, Exhibit AK95 6-5-02 OLIN/SC 037331.

[15] Kinsey, J.S. (2002) Characterization of Mercury Emissions at a Chlor-Alkali Plant, Volume I: Report and Appendices A-E. US Environmental Protection Agency, Office of Research and Development, National Risk Management Research Laboratory, Research Triangle Park, NRMRL-RTP-236a.

[16] United States Environmental Protection Agency (US EPA) (2003) Guideline on Air Quality Models, Revised. Office of Air Quality Planning \& Standards, Research Triangle Park. http://www.epa.gov/scram001/guidance/appw_03.pdf

[17] United States Environmental Protection Agency (US EPA) (1995) User's Guide for the Industrial Source Complex (ISC3) Dispersion Models, Volumes 1 \& 2. EPA-454/B-95-003a \& b, Office of Air Quality Planning \& Standards, Research Triangle Park.

[18] Keeler, G., Hoyer, M. and Lamborg, C. (1994) Measurements of Atmospheric Mercury in the Great Lakes Basin. In: Watras, C.J. and Huckabee, J.W., Eds., Mercury Pollution Integration and Synthesis, CRC Press, Boca Raton, 231-241. 
[19] Keeler, G., Glinsorn, F. and Pirrone, N. (1995) Particulate Mercury in the Atmosphere: It’s Significance, Transport, Transformation and Sources. Water, Air and Soil Pollution, 80, 159-168. http://dx.doi.org/10.1007/BF01189664

[20] Burke, J., Hoyer, M., Keeler, G. and Scherbatskoy, T. (1995) Wet Deposition of Mercury and Ambient Mercury Concentrations at a Site in the Lake Champlain Basin. Water, Air and Soil Pollution, 80, 353-362. http://dx.doi.org/10.1007/BF01189685

[21] Dvonch, J.T., Vette, A.F., Keeler, G.J., Evans, G. and Stevens, R. (1995) An Intensive Multi-Site Pilot Study Investigating Atmospheric Mercury in Broward Country, Florida. Water, Air and Soil Pollution, 80, 169-178. http://dx.doi.org/10.1007/BF01189665

[22] Fitzgerald, W.F., Mason, R.P. and Vandal, G.M. (1991) Atmospheric Cycling and Air-Water Exchange of Mercury over Mid-Continental Lacustrine Regions. Water, Air and Soil Pollution, 56, 745-767. http://dx.doi.org/10.1007/BF00342314

[23] Lamborg, C., Fitzgerald, W., Vandal, G. and Rolfhus, K. (1995) Atmospheric Mercury in Northern Wisconsin: Sources and Species. Water, Air and Soil Pollution, 80, 189-198. http://dx.doi.org/10.1007/BF01189667

[24] Amouroux, D., Wasserman, J.C., Tessier, E. and Donard, O.F.X. (1999) Elemental Mercury in the Atmosphere of a Tropical Amazonian Forest (French Guiana). Environmental Science and Technology, 33, 3044-3048. http://dx.doi.org/10.1021/es990119b

[25] Landis, M.S., Vette, A.F. and Keeler, G.J. (2002) Atmospheric Mercury in the Lake Michigan Basin: Influence of the Chicago/Gary Urban Area. Environmental Science and Technology, 36, 4508-4517. http://dx.doi.org/10.1021/es011216j

[26] Dommergue, A., Ferrari, C.P., Planchon, F.A.M. and Boutron, C.F. (2002) Influence of Anthropogenic Sources on Total Gaseous Mercury Variability in Grenoble Suburban Air (France). The Science of the Total Environment, 297, 203-213. http://dx.doi.org/10.1016/S0048-9697(02)00133-X

[27] Temme, C., Einax, J.W., Ebinghaus, R. and Schroeder, W.H. (2003) Measurements of Atmospheric Mercury Species at a Coastal Site in the Antarctic and over the South Atlantic Ocean during Polar Summer. Environmental Science and Technology, 37, 22-31. http://dx.doi.org/10.1021/es025884w

[28] Gustavsson, N., Bølviken, B., Smith, D.B. and Severson, R.C. (2001) Geochemical Landscapes of the Conterminous United States-New Map Presentations for 22 Elements, US Geological Survey Professional Paper 1648, US Department of the Interior, US Geological Survey.

[29] Kaminski, M D. and Landsberger, S. (2000) Heavy Metals in Urban Soils of East St. Louis, IL, Part I: Total Concentration of Heavy Metals in Soils. Journal of the Air and Waste Management Association, 50, 1667-1679. http://dx.doi.org/10.1080/10473289.2000.10464195

[30] Woodward Clyde Consultants (2002) 8/5/94; RCRA Facility Investigation Report for Buffalo Avenue Plant, Exhibit MB-15A.

[31] Woodward Clyde Consultants (1985) 5/3/85: Niachlor Soil Sampling Niagara Plant, Niagara Falls, New York.

[32] Malcolm Pirnie (1995) Supplemental RI, Vol. 1 of 2, Nov. 1994, Rev. July 1995.

[33] Ecology \& Environmental, Inc. (1990) Remedial Investigation Report Volume 1 Exhibit MR35 8/01/01.

[34] Dommergue, A., Ferrari, C.P., Planchon, F.A.M. and Boutron, C.F. (2002) Influence of Anthropogenic Sources on Total Gaseous Mercury Variability in Grenoble Suburban Air (France). The Science of the Total Environment, 297, 203-213. http://dx.doi.org/10.1016/S0048-9697(02)00133-X

[35] Ferrara, R., Maserti, B.E., Edner, H., Ragnarson, P., Svanberg, S. and Wallinder, E. (1992) Mercury Emissions into the Atmosphere from a Chlor-Alkali Complex Measured with the LIDAR Technique. Atmospheric Environment, 26A, 1253-1258. http://dx.doi.org/10.1016/0960-1686(92)90386-Y 